Jurnal Penelitian, Vol. 10, No. 2, Agustus 2016

\title{
MENGGAGAS PAYUNG HUKUM BAITUL MAAL WATTANWIL (BMT) SEBAGAI KOPERASI SYARI'AH DALAM BINGKAI IUS CONSTITUENDUM
}

\author{
Elfa Murdiana \\ Sekolah Tinggi Agama Islam Negeri Jurai Siwo Metro \\ elfamurdiana@yahoo.com
}

\begin{abstract}
Baitul Mal Wat Tanwil (BMT) is a syariah mOicrofinance institution which factually has positive influence on the progress of economic development in Indonesia. The fact, the existence of cooperative constitution has not been able to provide the legal basis in accordance with the existing practice of BMT. Therefore, the establishment of the certain rule of law cannot be postponed because the existence of BMT that has grown and develop well both from quantity aspect and capitalization. It is necessary for BMT to have own rule of law as the legal protection for the activities. It is because cooperation and BMT (aligned with syariah cooperation) differ operationally and principle. Thus, the establishment of syariah cooperative constitution as the legal basis of BMT should be held soon. In establishing the constitution of syari'ab cooperation in frame of Ius Constituendum, it must be noticed the three basic values. The First is justice value which founds philosophically the establishment of a rule of law (Filosofiche Geltung). The second is usefulness value which founds sociologically (siziologische geltung) in order to the law has the acceptable power in the society. The third is the conclusiveness value as the judicial foundation of a rule of law (Juridische Geltung); this foundation is related to formal requirement of a rule establishment. Moreover, political foundation means that the existence of a rule of law is an effort to put
\end{abstract}


Indonesia's collective ideas into a rule of law through the existed political power. In other word, it has relation to the authority that acts as legitimacy of a rule of law.

Keywords: BMT, Baitul Mal Wat Tanwil, Syariah Cooperation, Ius Constituendum).

\begin{abstract}
Abstrak
Baitul Maal Wat Tanwil (BMT) merupakan lembaga keuangan mikro syariah yang secara faktual telah memberikan pengaruh positif terhadap berlangsungnya pembangunan ekonomi di Indonesia. Secara faktual keberadaan UU Koperasi belum mampu memberikan dasar hukum yang sesuai dengan praktik. BMT yang ada. Perlu bagi BMT untuk memiliki aturan bukum tersendiri sebagai payung hukum bagi ak.tivitas BMT sebab Koperasi dan BMT (yang disejajarkan dengan Koperasi Syariah) berbeda secara operasional dan prinsip. Dalam rangka pembentukan UU Koperasi Syariah dalam kerangka Ius Constituendum perlu diperhatikan 3 nilai dasar, nilai dasar tersebut adalab: Nilai Keadilan yang mendasari secara filosofis terbentuknya suatu aturan bukum ( Filosofiche Geltung ). Kedua adalah nilai kemanfaatan yang mendasari secara sosiologis ( soziologische geltung) agar bukum memiliki kekuatan berlaku dimasyarakat. Ketika adalah nilai kepastian yang labir sebagai dasar yuridis suatu aturan bukum (Juridische Geltung), dasar ini terkait dengan persyaratan formal pembentukan suatu peraturan. Landasan politis artinya bahwa keberadaan suatu aturan bukum merupakan suatu upaya menuangkean cita-cita kolektif masyarakat Indonesia dalam suatu aturan bukum melalui kekuatan politis yang ada dengan kata lain dasar ini memiliki keterkaitannya dengan kekuasaan yang berperan sebagai legitimasi suatu aturan bukum.
\end{abstract}

Kata Kunci : BMT, Baitul Maal WatTanwil, Koperasi Syari'ah, Ius Constituendum.

\title{
A. Pendahuluan
}

Di akhir tahun 2012 tepatnya di bulan oktober pemerintah mengeluarkan kebijakan mengenai perkoperasian menggantikan Undang - Undang yang lama No.25 Tahun 1992. Kehadiran Undang - Undang Koperasi Baru No.17 Tahun 2012 menimbulkan dampak yang bukan hanya dirasakan oleh Koperasi 
Konvensional tetapi juga koperasi syari'ah atau yang lebih dikenal dengan sebutan BMT ( Baitul Maal Wa Tanwi).

Sebagai respon dari hadirnya Undang - Undang Koperasi tahun 2012 , koperasi-koperasi Indonesia termasuk BMT mulai melakukan perubahan terhadap kelembagaan ${ }^{1}$, keorganisasian ${ }^{2}$ dan permodalannya ${ }^{3}$. Belum lama UU Koperasi diberlakukan, di bulan Mei tepatnya pada tanggal 28 tahun 2014, kembali dunia perkoperasian diguncang oleh keputusan mahkamah konstitusi yang membatalkan Undang - Undang koperasi No.17 tahun 2012, Sebagai konsekuensi hukum dibatalkannya UU Koperasi 2012 maka mengenai perkoperasian kembali pada UU No. 25 Tahun 1992.

Pada hakikatnya, keberadaan UU Koperasi Baru tahun 2012 tidak begitu direspon positif oleh koperasi-koperasi yang ada terlebih bagi BMT walaupun secara substansi UU Koperasi tahun 2012 telah mengakomodir ketentuan mengenai dewan pengawas syari'ah. Sampai akhirnya UU Koperasi 2012 dibatalkan oleh Mahkamah Konstitusi sebab UU No.17 Tahun 2012 dirasakan kurang mendukung keberadaan BMT .

BMT sebagai Lembaga Keuangan Mikro Syari'ah,

${ }^{1}$ Perubahan ini adalah mengenai tatacara pendirian koperasi yang mensyaratkan akte otentik, fungsi dan jenis koperasi serta dimunculkannya lembaga penjamin simpanan dana nasabah. respon yang dilakukan oleh koperasi-koperasi di Indonesia termasuk BMT adalah dengan melakukan pendaftaran badan hukum koperasi melalui akte otentik yang akan disyahkan oleh Kementerian Koperasi Indonesia.

${ }^{2}$ Mengenai perangkat pengurus, yang menghilangkan istilah pengelola pada Undang - Undang yang baru . Pada Undang - Undang Koperasi yang lama dicantumkan dalam pasal 32 UU No. 25 Tahun 1992 bahwa pengurus koperasi dapat mengangkat pengelola yang diberi wewenang dan kuasa untuk mengelola usaha . Hilangnya keberadaan pengelola dalam UU yang baru tampak dalam ketentuan pasal 58 ayat 1 UU No.17 Tahun 2012 bahwa tugas pengurus adalah mengelola koperasi berdasarkan Anggaran Dasar artinya mengharuskan pengurus untuk mampu menggantikan peran pengelola di dalam upaya memajukan usaha koperasi.

${ }^{3}$ Modal koperasi diubah dalam bentuk saham , siapapun dapat membeli saham tersebut artinya baik anggota maupun non anggota dapat membelinya. Jelas ini sudah melenceng dari tuhuan awal pendirian koperasi sebagaimana amanah UUD 1945. 
kedudukannya sejajar dengan Koperasi. BMT merupakan bentuk Badan usaha yang berbadan hukum Koperasi sehingga BMT sama-sama berdiri di bawah naungan Dinas Koperasi , namun secara operasional BMT dijalankan berdasarkan prinsip syari'ah ${ }^{4}$, hal inilah yang membedakan BMT dengan koperasi. BMT adalah lembaga swadaya masyarakat, dalam artinya, didirikan dan dikembangkan oleh masyarakat. Terutama sekali pada awal pendiriannya, biasanya dilakukan dengan mengunakan sumber daya, termasuk dana atau modal, dari masyarakat setempat itu sendiri. ${ }^{5}$ Dan secara fungsional BMT sebagai Koperasi syari'ah memiliki peran dan fungsi penting yaitu: ${ }^{6}$ Sebagai Menejer Investasi ${ }^{7}$, Sebagai Investor ${ }^{8}$ dan Fungsi sosial dimana Fungsi sosial ini juga memiliki arti bahwa BMT harus memberikan pelayanan baik kepada anggota maupun masyarakat dhu'afa. Begitupun bila ada anggota yang membutuhkan pinjaman darurat / emergency loan maka BMT harus memberikan pinjaman kebajikan yang disebut Qord Hasan. Fungsi sosial inilah yang membedakan BMT dengan Koperasi konvensional lainnya.

Secara implementatif, keberadaan BMT saat ini sudah banyak dikenal oleh masyarakat Indonesia. Berbagai produk yang ditawarkan baik produk jasa maupun keuangan dengan model akad yang bervarian dan dapat dipilih sesuai kebutuhan masyarakat, menjadikan BMT sebagai lembaga keuangan yang mampu bersaing dengan lembaga keuangan lainnya termasuk

${ }^{4}$ Nur S Bukhori, Koperasi Syari'ah Teori dan Praktik (Tanggerang Selatan: Pustaka Aufa Media, 2012), hlm. 3.

${ }^{5}$ Euis Amalia, Keadilan Distributif Dalam Ekonomi Islam, (Jakarta: PT Rajagrafindo Persada, 2009), hlm. 82.

${ }^{6}$ Ibid, hlm. 14-15.

${ }^{7}$ Fungsi ini memiliki peran bahwa koperasi memegang peranan sebagai agent penghubung bagi para pemilik dana untuk kemudian disalurkan kepada calon atau anggota yang membutuhkan sehingga BMT akan memperoleh pendapatan berdasarkan jasa agennya.

${ }^{8}$ BMT sebagai Koperasi syariah memiliki peran sebagai shahibul maal . bila dana yang diperoleh dari anggota maupun pinjaman dari pihak lain maka BMT harus mengelola secara profesional dan efektif tanpa persyaratan khusus dari pemilik dana dan BMT memiliki hak untuk mengelola berdasarkan produk syari'ah yang dimiliki seperti murabahah, mudharabah maupun musyarakah.. 
perbankan.

Dari uraian diatas tergambar bahwa secara operasional sesungguhnya BMT berbeda dengan Koperasi . Aktivitas BMT justru sejajar dengan aktivitas yang dilakukan perbankan syari'ah bahkan produk-produk yang ditawarkan oleh BMT jauh lebih implementatif dari pada perbankan syari'ah. Oleh karenanya pemberlakuan UU Koperasi bagi BMT dirasa belum dapat memenuhi aspek kepastian bahkan kemanfaatan hukum bagi aktifitas BMT. ${ }^{9}$ Faktanya aturan hukum bagi aktivitas BMT masih berpayung pada UU Koperasi.

Sebagai akibat dari prinsip Rechtstaats, maka segala aktifitas yang dilakukan harus berdasarkan atas hukum yang sah dan berlaku di Negara Indonesia. Oleh karenanya legislasi aturan hukum bagi BMT harus segera dibentuk, mengingat pertumbuhan dan perkembangan BMT di Indonesia saat ini telah mengalami peningkatan ${ }^{10}$. Nantinya segala aktivitas yang dilakukan memiliki kepastian hukum sebagaimana perbankan syari'ah yang memiliki aturan hukum tersendiri yang berbeda dengan aturan hukum bagi perbankan konvensional.

Berbicara mengenai pembentukan aturan hukum maka terdapat 3 Alasan yang akan melahirkan nilai-nilai yang menjadikan aturan hukum berlaku efektif dimasyarakat. 3 alasan tersebut adalah filosofis, sosiologis dan yuridis dimana ketiga alasan tersebut akan melahirkan nilai keadilan, kemanfaatan dan kepastian hukum. ${ }^{11}$ Dan dari ketiga alasan serta nilai yang ada, alasan filosofis yang menjadi alasan utama bagi pembentukan suatu aturan hukum. Alasan filosofis tersebut akan melahirkan nilai keadilan, dan untuk mencapai nilai tertinggi tersebut yaitu

${ }^{9}$ Pernyataan ini diperkuat dengan hasil wawancara penulis dengan pengurus BMT di Kota Metro (BMT Fadjar, BMT Alihsan, BMT Arsyada dan Adzkiya) yang menjadi sumber data primer dalam penelitian penulis di Tahun 2013 mengenai Respon BMT Kota Metro Terbadap UU Koperasi Tabun 2012.

${ }^{10}$ Berdasarkan hasil olah data penulis bahwa di kota Metro lampung jumlah BMT yang terdaftar sebagai anggota Puskopsyah terahir mencapai 30 BMT, yang tidak menjadi anggotapun masih banyak. Bahkan di Indonesia Jumlah BMT sudah mengalami peningkatan yang luar biasa.

${ }^{11}$ Soerjono Soekanto, Beberapa Permasalahan Hukum dalam Kerangka Pembangunan di Indonesia, ( Jakarta: Yayasan Penerbit UI, 1975), hlm. 5-6. 
keadilan maka aturan hukum yang dibentuk haruslah pasti dan bermanfaat. Singkatnya bahwa hukum adalah alat mencapai Tujuan yaitu Keadilan.

Dalam rangka memberikan keadilan bagi masyarakat maka hukum harus di himpun dalam suatu kitab undang-undang yang memuat secara jelas tujuan diciptakannya hukum. ${ }^{12} \mathrm{Hal}$ tersebut dilakukan agar masyarakat dapat mengetahui secara jelas , memahami dan menaati aturan hukum tersebut. Tentunya perumusan tujuan tersebut merupakan tujuan yang diinginkan oleh seluruh masyarakat sebagai dasar sosiologis dalam pembentukan hukum.

Karena hukum merupakan wujud keadilan melalui pemenuhan kehendak rakyat maka, aspirasi pelaku koperasi syari'ah dalam hal ini BMT menjadi sangat penting ,sebab untuk memahami dan menaatinya hukum harus dibentuk atas dasar keinginan dan kebutuhan masyarakat dalam hal ini adalah pelaku koperasi syariah yaitu BMT. Oleh karenanya dalam artikel ini akan dikemas berbagai aspirasi BMT sebagai dasar sosiologis untuk memberikan kepastian hukum yang berdampak pada keadilan bagi seluruh BMT di Indonesia. Diharapkan bahwa gagasan ini dapat bermanfaat sebagai Ius Constiutuendum terhadap pembentukan aturan hukum untuk BMT.

Artikelinimenggunakanpendekatan sosiologicaljurisprudence $e^{13}$ pada penelitian (Field Research) untuk mendeskripsikan analisa data kualitatif dari wacana pembentukan aturan hukum bagi BMT melalui gagasan-gagasan yang diperoleh dari hasil penelitian BMT sebagai populasinya.

Sumber data merupakan tempat dimana data penelitian ini didapat. Dalam penulisan ini sumber data yang peneliti gunakan dibagi menjadi 2 yaitu:

\section{${ }^{12}$ Ibid.}

${ }^{13}$ suatu pendekatan sosiologis yang melihat pada gejala gejala yang hidup di masyarakat (law in action) sebagai upaya untuk merumuskan suatu peraturan perundangan (law in books). dalam kaitannya dengan penelitian ini penulis akan merumuskan konsep UU Koperasi Syari'ah sebagai Law in book's melalui aspirasi dan pemikiran yang diperoleh dari pelaku koperas syari'ah (law in action) di BMT yang berada di kota Metro. 
a. Sumber Data primer merupakan sumber data utama yang digunakan dalam penelitian ini, sumber data primer. data primer adalah data yang peneliti peroleh langsung dari sumber aslinya. Data ini peneliti diperoleh langsung melalui beberapa tekhnik diantaranya:

1) Observasi adalah kegiatan peninjauan yang dilakukan di lokasi penelitian . observasi yang dilakukan dalam 2 tahap yaitu pada tahap awal guna mendapatkan data pertama. Observasi dilakukan pada saat pengumpulan data lapangan guna pengolahan dan penyusunan laporan penelitian. Tekhnik observasi yang peneliti lakukan sejalan dengan yang dikemukakan oleh Prof Abdul Kadir Muhammad dalam buku Hukum dan Penelitian Hukum. ${ }^{14}$

2) Wawancara yaitu teknik pengumpulan data dengan mengajukan pertanyaan langsung kepada responden, dan jawaban-jawaban responden dicatatatau direkam. ${ }^{15}$ Terkait dengan penulisan artikel ini, digunakan tekhnik wawancara tidak terstruktur atau disebut juga wawancara terbuka (Open-ended interview) ${ }^{16}$

b. Sumber Data Sekunder, merupakan data pendukung dari data primer dan data ini merupakan data jadi seperti peraturan hukum yaitu UU Koperasi No. 17 Tahun 2012 , Keputusan MK No.28 tahun 2014 Tentang Pembatalan UU Koperasi Tahun2012 serta buku-buku dan jurnal penelitian yang terkait dengan kajian mengenai koperasi dan koperasi syariah/BMT.

${ }^{14}$ Abdul Kadir Muhammad. Hukum dan Penelitian Hukum, Jakarta: PT. Citra Aditya Bhakti, 2004), hlm. 85.

${ }^{15}$ Burhan Ashshofa, Metode Penelitian Hukum, (Jakarta: Rineka Cipta, 2002), hlm. 91.

${ }^{16}$ Bandingkan dengan tekhnik wawancara yang dikemukakan oleh Burhan Asshofa, Metode Penelitian Hukum, (Jakarta: Rieneka Cipta, 2002), h..96. Burhan Asshofa memaparkan bahwa tekhnik wawancara dibagi menjadi 2 yaitu berencana dan tidak berencana. 
Data primer mengenai substansi Aturan Hukum BMT akan disajikan dengan menggunakan alur berfikir induktif ${ }^{17}$ pada kerangka umum mengenai teori pembentukan hukum sebagai dasar yang menjadikan suatu aturan hukum mampu menyajikan dan memberikan keadilan bagi masyarakat secara umum dan bagi para pelaku BMT.

\section{B. Pembahasan}

\section{Definisi Konsep}

a. Baitul Maal Wa Tamwil (BMT)

Baitul mal Wa at-Tamwil (BMT) adalah lembaga swadaya masyarakat, dalam artinya, didirikan dan dikembangkan oleh masyarakat. Terutama sekali pada awal pendiriannya, biasanya dilakukan dengan mengunakan sumber daya, termasuk dana atau modal, dari masyarakat setempat itu sendiri. ${ }^{18}$

BMT memiliki dua latar belakang pendirian dan kegiatan yang hampir sama kuatnya, yakni sebagai lembaga keuangan mikro dan sebagai lembaga keuangan syariah. Eksistensinya memang belum diketahui secara luas oleh masyarakat, serta masih melayani kelompok masyarakat yang relatif homogen. Selain cakupan geografis yang amat terbatas, dampak ekonomis dari kegiatannya pun terbilang masih amat minimal. Bagaimanapun, ciri dan latar belakang dimaksud sudah teridentifikasi secara cukup jelas. Fenomena kehadirannya secara bersama-sama telah mulai dikenal sebagai gerakan BMT.

Baitul Maal wat Tamwil (BMT) merupakan badan usaha berbadan hukum ${ }^{19}$ koperasi, sehingga segala aktivitasnya harus melalui prosedur yang telah ditetapkan oleh Dinas Koperasi .

${ }^{17}$ Alur berfikir yang berangkat dari kondisi nyata yang terjadi dimasyarakat lalu akan dianalisis kesesuaiannya dengan kerangka berfikir secara umum mengenai teori pembentukan hukum, singkatnya bahwa induktif dalam hal ini adalah upaya mengkontruksikan gagasan nyata kepada kerangka teori yang digunakan.

${ }^{18}$ Euis Amalia, Keadilan Distributif Dalam Ekonomi Islam, (Jakarta: PT Rajagrafindo Persada, 2009), hlm. 82.

${ }^{19}$ Artinya bahwa koperasi berkedudukan sebagai subyek hukum yaitu recht persoon yang memiliki hak dan kewajiban sama dengan subyek hukum manusia dalam aktivitas hukum seperti dapat melakukan tunttutan maupun gugatan hukum dan dapat dituntut dan digugat secara hukum. 
Namun BMT dijalankan dengan prinsip syari'ah oleh karenanya BMT disebut juga sebagai Koperasi Syari'ah. BMT melaksanakan dua jenis kegiatan, yaitu sebagai Baitul Maal dan Baitul Tamwil. Sebagai Baitul Maal, BMT menerima titipan zakat, infaq, dan shadaqah serta menyalurkan (tasaruf) sesuai dengan peraturan dan amanahnya, dapat dikatakan bahwa sebagai baitul maal BMT berperan dan memiliki fungsi sosial. Sedangkan sebagai Baitul Tamwil, BMT memiliki tujuan awal untuk mengembangkan usaha-usaha produktif dan investasi dalam meningkatkan kualitas kegiatan pengusaha kecil bawah dan kecil dengan mendorong kegiatan menabung dan menunjang pembiayaan ekonomi.

Sebagai Baitul Tamwil, BMT merupakan lembaga keuangan syariah yang memiliki fungsi hampir sama dengan lembaga perbankkan makro, yaitu melakukan upaya penghimpunan dan penyaluran dana. Namun BMT sebagai suatu badan usaha koperasi memiliki fungsi intermediasi yang khusus artinya penghimpunan dana dan penyaluran dana ini tidak mencakup keseluruhan masyarakat sebagaimana lembaga perbankan, tetapi hanya kepada anggota mereka saja. Tentunya sebagai Koperasi syari'ah BMT dijalankan dengan menggunakan prinsip syariah, inilah yang membedakan BMT dengan koperasi-koperasi yang lainnya.

b. Ius Constituendum

Ius memiliki pengertian yang lebih luas dibanding dengan lex atau lege karena ius merupakan suatu cita hukum yang tercermin dari aturan tersebut, cita hukum tersebut adalah keadilan. Oleh karenanya Leon Duguit mengatakan bahwa hukum merupakan karya sosial yang dampaknya adalah pada ketaatan hukum masyarakat tersebut, untuk kemudian akan muncul sebuah keadilan. Ius Constituendum diartikan sebagai hukum yang dicita-citakan. Wacana pembentukan UU Koperasi Syari'ah bagi BMT merupakan proses pembentukan Ius Constituendum

\section{BMT sebagai Badan Hukum Koperasi Syari'ah}

Koperasi Syari'ah merupakan lembaga keuangan yang dijalankan berdasarkan prinsip syari'ah, tentu lahirnya koperasi 
syari'ahinijuga dipengaruhiolehkeberadaankoperasikonvensional. Koperasi syari'ah lahir diawali oleh gerakan ekonomi Islam yang kemudian melahirkan BMT (Baitul Maal wa Tanwil) yang pada tahun1992 ternyata mampu memberi warna bagi kalangan akar rumput yaitu pengusaha mikro. ${ }^{20}$ Oleh karenanya BMT disebut sebagai koperasi syari'ah maka konsekuensinya BMT harus tunduk pada UU Koperasi . Kenyataanya sistem operasional yang dijalankan BMT dengan Koperasi sangat berbeda diamana perbedaannya dapat terlihat dari prinsip syari'ah yang dijalankan.

Sebagai badan hukum koperasi artinya bahwa BMT merupakan subyek hukum yang difiksikan seperti manusia sebagai subyek hukum sehingga BMT memiliki hak dan kewajiban sama sebagai subyek hukum dengan manusia demikian gambaran dari teori fiksi yang mendukung badan hukum sebagai subyek hukum.

\section{Politik Hukum Koperasi di Indonesia}

Proses pembentukan hukum merupakan proses sosial dan proses politik yang sangat penting artinya, sebab dengan pembentukan hukum ini akan dapat memberikan pengaruh yang sangat luas dalam mengatur dan mengendalikan masyarakat kerena hukum juga dianggap merupakan salah satu alat dan sarana untuk mencapai suatu tujuan tertentu oleh suatu negara. pada hakikatnya upaya tersebut tidak dapat terlepas dari tujuan penanggulangan terjadinya suatu perbuatan melanggar hukum. Proses demikian dikatakan sebagai Politik Hukum. ${ }^{21}$

Politik hukum juga merupakan bagian integral dari politik sosial (social Policy). ${ }^{22}$ Oleh karenanya hukum harus benar-benar diarahkan untuk memberikan keadilan bagi masyarakat, sebab hukum dipandang sebagai sarana keadilan sebagaimana yang dikemukakan oleh Plato $^{23}$ bahwa hukum merupakan tatanan

${ }^{20}$ Nur S Bukhori, Koperasi Syari'ab Teori dan Praktik, (Tanggerang Selatan: Pustaka Aufa Media, 2012), hlm. 3.

${ }^{21}$ M. Hamdan, Politik hukum Pidana, (Jakarta: Raja Grafindo Persada, 1997) hlm. 21.

${ }^{22} \mathrm{Ibid}, \mathrm{hlm} .24$.

${ }^{23}$ Plato adalah pencetus ajaran tentang kebenaran / ideal (ideenleer) yang membedakan antara gejala sebagai fenomena nyata yang terjadi dan eidos sebagai 
terbaik untuk menangani dunia fenomena yang penuh situasi ketidakadilan. ${ }^{24}$

Di Indonesia kebijakan mengenai perkoperasian sudah sejak lama ada seiring dengan keberadaan koperasi. pada tahun 1958 kebijakan tentang perkoperasian diatur dalam UU No. 79 Tahun 1958 . UU No. 79 Tahun 1958 bertitel tentang perkumpulan perkoperasian . lalu pada tahun 1965 kebijakan tetang perkoperasian diperbaharui dengan lahirnya UU No.14 Tahun 1965 dengan titel Undang - Undang tentang Perkoperasian.

Pada tahun 1992 kembali dilakukan perubahan mengenai UU Perkoperasian tepatnya UU No. 25 Tahun 1992, kemudian ditahun 2012 kembali dilakukan perubahan UU Koperasi seiring dengan perkembangan aktivitas koperasi di Indonesia. Lahirnya UU No. 17 Tahun 2012 Tentang perkoperasian banyak menimbulkan pro-kontra, sebaab banyak hal berbeda yang coba ditampilkan dalam rangka memperkuat koperasi Indonesia. Perbedaan tersebut diantaranya.

dunia ideal , bila dibandingkan dengan pemikiran Immanuel Kant mengenai dua prinsip imperatif yaitu sollen dan sein. Sollen merupakan bidang akal praktis seperti hukum, norma , kaidah sedangkan sein merupakan bidang akal murni seperti alam fakta dan semua yang dapat dilihat oleh panca indera maka dunia gejala disebut juga dengan sein dan eidos sebagai sollen.

${ }^{24}$ Bernard L Tanya, dkk., Teori Hukum Strategi Tertib Manusia Lintas Ruang dan Generasi (Yogyakarta: Genta Publishing, 2010), hlm. 41. 
Tabel 1. Perbedaan Undang-Undang Tentang Koperasi

\begin{tabular}{|c|c|c|}
\hline \multirow[b]{2}{*}{ No. } & \multicolumn{2}{|c|}{ Perbedaan } \\
\hline & $\begin{array}{lll}\text { Undang-undang } & \text { No. } & 25 \\
\text { Tahun } 1992 & & \\
\end{array}$ & $\begin{array}{l}\text { Undang-undang No } 17 \text { Tahun } \\
2012\end{array}$ \\
\hline 1 & $\begin{array}{l}\text { Koperasi sebagai badan } \\
\text { Usaha dan badan hukum }\end{array}$ & $\begin{array}{l}\text { Koperasi sebagai badan } \\
\text { hukum }\end{array}$ \\
\hline 2. & $\begin{array}{l}\text { Tidak terjadi konsistenan } \\
\text { kata dalam menguraikan } \\
\text { definisi koperasi yakni } \\
\text { dilain hal koperasi } \\
\text { dijabarkan sebagai badan } \\
\text { usaha tetapi disisi lain } \\
\text { koperasi dijabarkan } \\
\text { sebagai badan hukum } \\
\end{array}$ & $\begin{array}{l}\text { Terjadi konsistenan kata yakni } \\
\text { menguraikan definisi koperasi } \\
\text { sebagai badan hukum }\end{array}$ \\
\hline 3. & $\begin{array}{l}\text { Tidak menguraikan lebih } \\
\text { jelas komposisi modal yang } \\
\text { dimiliki koperasi dalam } \\
\text { hal pemisahaan kekayaaan } \\
\text { para anggotanya }\end{array}$ & $\begin{array}{l}\text { menguraikan lebih jelas } \\
\text { komposisi modal yang } \\
\text { dimiliki koperasi dalam hal } \\
\text { pemisahaan kekayaaan para } \\
\text { anggotanya }\end{array}$ \\
\hline 4. & $\begin{array}{l}\text { Menguraikan Cakupan } \\
\text { Koperasi Hanya Sebatas } \\
\text { Pada Bidang Ekonomi. }\end{array}$ & $\begin{array}{l}\text { Menguraikan definisi yang } \\
\text { lebih luas yang menyatakan } \\
\text { koperasi tidak hanya } \\
\text { mencangkup kebutuhan } \\
\text { ekonomi semata tetapi pula } \\
\text { bidang ekonomi, sosial, dan } \\
\text { budaya. }\end{array}$ \\
\hline 5. & $\begin{array}{l}\text { Menguraikan prinsip } \\
\text { koperasi sebagai pedoman } \\
\text { yang dianut koperasi. }\end{array}$ & $\begin{array}{l}\text { Tidak hanya menguraikan } \\
\text { prinsip koperasi sebagai } \\
\text { pedoman untuk menjalankan } \\
\text { kegiatan operasional tetapi } \\
\text { juga berpedoman pada nilai }\end{array}$ \\
\hline 6. & $\begin{array}{lr}\text { Menguraikan prinsip } \\
\text { koperasi tidak } \\
\text { menekanya } \\
\text { keanggotaan sifat } \\
\text { pengelolaan koperasi tetapi } \\
\text { juga merekan penekanan } \\
\text { terhadap balas jasa dari sisa } \\
\text { hasil usaha yang diperoleh. }\end{array}$ & $\begin{array}{l}\text { Menguraikan prinsip koperasi } \\
\text { lebih menekankan pada } \\
\text { pelayanan prima sebagai } \\
\text { prinsip koperasi dan merevisi } \\
\text { penekanan balas jasa dari sisa } \\
\text { hasil usaha yang diperoleh } \\
\text { karena hal ini dianggap bukan } \\
\text { sebagai prinsip koperasi } \\
\text { yang menekankan makna } \\
\text { pelayanan. }\end{array}$ \\
\hline
\end{tabular}




\begin{tabular}{lll}
\hline menguraikan definisi & tidak menguraikan definisi \\
k. & koperasi yang berdasarkan & koperasi yang berdasarkan \\
atas sas kekeluargaan. & atas asas kekeluarga \\
\hline
\end{tabular}

\section{Potensi BMT sebagai Lembaga Pemberdayaan Keuangan}

BMT sebagai lembaga keuangan yang bergerak pada skala mikro memiliki potensi luar biasa dalam mengembangkan usaha masyarakat menengah kebawah. Dengan kemudahan yang diberikan menjadikan BMT semakin dikenal dan dipilih sebagai lembaga keuangan yang membantu kebutuhan permodalan melalui pembiayaan baik yang bersifat produktif maupun konsumtif dimasyarakat. Hal ini menunjukkan bahwa BMT mampu tampil dan berperan sebagai lembaga intermediasi keuangan.

Sebagai lembaga keuangan syari'ah BMT selalu mendasarkan semua aktivitas dengan prinsip-prinsip syari'ah. Prinsip syariah yang paling mendasar dan yang sering digunakan adalah sistem bagi hasil yang adil, baik dalam hal penghimpunan maupun penyaluran dana. Sistem bagi hasil tersebut dikenal dengan sebutan profit and loss sharing, di mana hal ini dapat diartikan sebagai pembagian antara untung dan rugi dari pendapatan yang diterima atas hasil usaha yang telah dilakukan. Sampai sejauh ini, kebanyakan BMT berupaya menjalankan fungsi keuangan syariah tersebut secara profesional dan patuh kepada prinsip syariah.

Pertumbuhan jumlah BMT yang didukung dengan pertumbuhan modal yang dimiliki suatu BMT dari tahun-ketahun menjadi bukti bahwa keberadaan BMT sudah sangat diterima masyarakat bahkan secara faktual produk maupun aktivitas BMT sama halnya dengan aktivitas perbankan. Adi seorang pedagang buah di pasar kota Metro menyatakan bahwa pelayanan dan persyaratan yang diberikan oleh BMT tidak berbelit belit dan tidak memakan waktu lama, sehingga keperluan modal yang diinginkan dapat segera terpenuhi. Begitupun penuturan Bu Siti seorang penjual ikan asin pasar Metro yang menjelaskan bahwa dengan BMT usaha ikan asinnya menjadi maju karena kebutuhan 
modal terpenuhi dengan segera. ${ }^{25}$

Pada BMT yang telah lama beroperasi, per modalan yang dimiliki pun semakin kuat sehingga pembiayaan yang diberikan tidak lagi dalam jumlah kecil . Maka gambaran kondisi diatas menjadi dasar pembuktian mengenai potensi BMT .

\section{Hukum Sebagai Alat Mencapai Keadilan}

Berbicara tentang keadilan maka akan sangat terkait dengan pembahasan mengenai tujuan hukum. Dalam kajian teori hukum diadakan atau dibuat untuk mencapai keadilan dimana Teori Etis merupakan dasar yang menjadi dasar pijakan keadilan tersebut. Dalam kaitannya dengan kajian tujuan hukum awalnya dikatakan bahwa hukum bertujuan untuk menciptakan ketertiban, kedamaian dalam masyarakat, menjaga dan melindungi masyarakat, menegakkan keadilan dan menjaga kepentingan individu maupun masyarakat dan lain-lain.

Menurut Prof. Subekti SH dalam bukunya Dasar-Dasar Hukum Pengadilan mengatakan bahwa hukum mengabdi pada tujuan Negara yang pada pokoknya bertujuan untuk mendatangkan kemakmuran dan kebahagiaan pada rakyatnya artinya bahwa hukum itu melayani tujuan Negara dengan menyelenggarakan "Keadilan dan Ketertiban" sebagai syarat pokok untuk mendatangkan kemakmuran dan kebahagiaan dimana Keadilan digambarkan sebagai suatu keadaan keseimbangan yang membawa ketentraman dalam hati seseorang yang jika diusik atau dilanggar akan menimbulkan kegelisahan dan kegoncangan.

Tujuan hukum ialah mengatur pergaulan secara damai karena hukum menghendaki adanya perdamaian dengan melindungi kepentingan hukum manusia seperti kehormatan, kemerdekaan, jiwa harta benda. Secara teoritis uraian mengenai tujuan hukum ini, dalam perkembangannya tidak terlepas dari beberapa teori diantaranya:

${ }^{25}$ Hasil wawancara penulis dengan pedagang pasar Metro pada 25 September 2014. 


\section{a. Teori Etis}

"Hukum semata-mata harus ditentukan oleh kesadaran etis tentang apa yang adil dan apa yang tidak adil " artinya bahwa menciptakan keadilan berarti memberikan apa yang menjadi hak setiap orang. ${ }^{26}$

Teori ini memiliki kelemahan yaitu sulit dilaksanakan karena makna keadilan sulit dirumuskan. Seperti dikatakan sebelumnya bahwa adil artinya memberikan sesuatu yang menjadi haknya artinya untuk menciptakan keadilan maka harus menciptakan hukum yang berlaku khusus bagi tiap individu, maka keadilan baru tercipta jika sudah tercipta hukum bagi kasus demi kasus. Hal tersebut tentu saja tidaklah mungkin karena akan menciptakan ketidakpastian hukum dan juga bertentangan dengan prinsip bahwa hukum itu harus berlaku umum dan mengikat setiap orang. Maka atas dasar ini teori etis ini dianggap berat sebelah. Aristoteles menjabarkan 2 macam keadilan:

Pertama: keadilan distributive yaitu keadilan yang didistribusikan sesuai dengan jasa dan kemampuannya. Keadilan distributive ini lazimnya akan terkait dengan hukum public suatu Negara. Kedua keadilan Komulatif yaitu kepada setiap orang diberikan sesuatu yang sama tanpa membedakan dan melihat apa yang telah dilakukan. Ulpianus dan Thomas Aquinas mendefinisikan keadilan sebagai kehendak yang menetap untuk diberikan kepada masing-masing orang akan bagiannya/ haknya.

\section{b. Teori Utilitis (Jeremy Bentham)}

Bahwa tujuan hukum adalah untuk memberikan kemanfaatan bagi orang sebanyak-banyaknya, agar hukum bermanfaat maka keadilan dikorbankan. Teori ini juga banyak ditentang karena bercorak sepihak sebab hukum baru mendatangkan manfaat jika hukum telah dapat mendatangkan kemanfaatan dan untuk mendatangkan kemanfaatan hukum kadang harus mengorbankan keadilan sehingga keadilan terabaikan dan pengabaian keadilan artinya hukum akan diidentikkan dengan kekuasaan. ${ }^{27}$

${ }^{26}$ Sudikno, Mengenal Hukum, (Yogyakarta: Liberty, 1999), hlm. 75.

${ }^{27}$ Ibid., hlm. 76. 


\section{c. Teori Campuran (Mochtar Kusumaatmadja)}

Tujuan hukum adalah untuk mengatur pergaulan secara damai mengakomodasikan antara keadilan, kemanfaatan dan kebahagiaan sebagai tujuan hukum, namun tujuan pokok hukum adalah untuk ketertiban karena ketertiaban merupakan syarat pokok bagi adanya suatu masyarakat yang teratur. ${ }^{28}$

Keberadaan BMT yang secara nyata telah mengalami pertumbuhan bahkan memberikan pengaruh yang tidak sedikit dalam pembangunan ekonomi harusnya telah ditopang oleh dasar hukum yang kuat dan jelas namun tidak demikian senyatanya. Selama ini BMT tunduk pada Undang-Undang Koperasi sebagai konsekuensi badan hukum koperasi yang dipilih. Namun sesungguhnya BMT dan Koperasi memiliki perbedaan operasional dan sistem yang dilakukan.

Hukum merupakan sebuah alat untuk memberikan keadilan dan keadilan akan bisa dicapai bila sudah tercapai kepastian dan kemanfaatan. Oleh karenanya pembentukan payung hukum bagi BMT adalah sebuah keharusan untuk menunjang stabilitas aktivitas BMT yang sehat dan legal. Sebagaimana yang dikemukakan oleh Sunaryati Hartono dalam tulisannya yang berjudul "Perspektif Politik Hukum Nasional “ memberikan gambaran bahwa hukum bukan sebuah tujuan tetapi hukum merupakan sarana atau jembatan yang harus membawa kita pada hukum yang dicita-citakan. ${ }^{29}$ Lebih lanjut Sunaryati mengemukakan bahwa untuk menjadikan hukum sebagai sarana mencapai tujuan maka terlebih dahulu harus diketahui mengenai masyarakat yang dicita-citakan oleh bangsa Indonesia, sehingga akan tercapai sistem hukum nasional yang dikehendaki oleh seluruh masyarakat Indonesia. ${ }^{30}$

Selain dari pada hal tersebut diatas, dalam rangka mencapai cita dan tujuan adanya BMT sebagai lembaga keuangan mikro syari'ah maka hendaknya perlu diupayakan hukum yang aturan

${ }^{28} \mathrm{Ibid}$

${ }^{29}$ Sunaryati Hartono, Politik Hukum Menuju Sistem Hukum Nasional, (Bandung: Alumni, 1991), hlm. 1.

${ }^{30}$ Ibid., hlm 13. 
hukum yang merupakan bentuk karya sosial pegiat BMT sehingga nantinya terpenuhi dasar kemanfaatan aturan hukum yang telah dibuat untuk memberikan keadilan bagi BMT. Sebagaimana yang dikemukakan oleh Leon Duguit bahwa hukum merupakan karya sosial yang dampaknya adalah pada ketaatan hukum masyarakat tersebut, untuk kemudian akan muncullah sebuah keadilan.

\section{Respon Atas Dibatalkannya UU Koperasi No.17 tahun 2012}

Dibatalkannya UU Koperasi Tahun 2012 oleh Mahkamah Konstitusi karena secara substansial UU Koperasi Tahun 2012 bertentangan dengan UUD 1945 yang menjunjung tinggi semangat demokrasi ekonomi. Keberadaan UU Koperasi tahun 2012 dianggap tidak relevant secara filosofis, sosiologis dan yuridis sebagai peraturan hukum yang berlaku secara umum. Sebab banyak kalangan menilai bahwa kehadiran Undang - Undang ini justru mereduksi semangat kekeluargaan yang merupakan ciri khas koperasi. dalam ketentuan koperasi terbaru ini lebih menonjolkan semangat kapitalisme daripada semangat ekonomi rakyat, sebab dalam sejarah di ketahui bahwa koperasi itu lahir di Indonesia karena bertujuan untuk meningkatkan kemakmuran masyarakat melalui upaya pemberdayaan ekonomi sesuai dengan kemampuan rakyat atau yang dulu dikenal dengan prinsip sukarela.

Bahkan kekhawatiran yang berkembang bahwa dengan lahirnya Undang-Undang koperasi terbaru ini justru menimbulkan banyak kekhawatiran. Salah satu kekhawatiran tersebut timbul dikarenakan kuatnya fungsi pengawasan dalam Undang - Undang koperasi baru dengan menghilangkan pengelola.

Tidak hanya pada itu, pada undang - undang baru juga dihilangkan istilah simpanan pokok, simpanan wajib dan simpanan sukarela, dengan memunculkan istilah setoran pokok dan sertifikat modal koperasi pada saat pendirian. Menghapus istilah-istilah tersebut, sebenarnya tak perlu dilakukan karena pada hakekatnya memiliki makna yang sama. Simpanan wajib ini akan menjadi keterikatan anggota, selanjutnya loyalitas anggota terhadap koperasi akan terlihat. 
Direduksinya semangat demokrasi ekonomi, gotong royong dan kekeluargaan terjadi karena pembentuk kebijakan tidak mempertimbangkan kajian sosiologis dalam pembentukan peraturan hukum sehingga kehadiran Undang - Undang Koperasi tahun 2012 ini dirasa tidak dapat memberikan nilai manfaat bagi para pelaku koperasi termasuk BMT, sebab substansi Undang Undang tersebut justru mencabut ruh demokrasi ekonomi dan menciptakan kapitalisasi ekonomi dalam koperasi.

Kehadiran UU No. 17 tahun 2012 tentang koperasi yang menegaskan adanya kejelasan fungsi koperasi sebagaimana tersebut dalam pasal 83 mengenai jenis koperasi, dianggap telah mengebiri semangat syari'ah, sebab bila BMT hanya menjalankan fungsi simpan pinjam saja maka sebagai KSPS (koperasi simpan pinjam syari'ah) harus melaksanakan simpan pinjam secara syari'ah secara sempit yang melenceng dari prinsip syari'ah dalam bermu'amalah. Sehingga dapat dikatakan UU No. 17 Tahun 2012 jauh dari nilai kemanfaatan sebagai dasar berlakunya Undang - Undang tersebut secara sosiologis yang akan diterima dan dilaksanakan.

Belum usai kegalauan pelaku koperasi dan BMT, pada tahun 2014 kembali dikejutkan dengan dibatalkannya UU No.17 Tahun 2012 tentang koperasi, sebab sejak diberlakukannya UU Koperasi Tahun 2012 telah diupayakan penyesuaian-penyesuaian yang tidak memakan biaya sedikit. Oleh karenanya inisiatif perkumpulan BMT di Kota Metro bersama dengan asosiasi BMT se-Indonesia melakukan berbagai upaya agar keberadaan BMT menjadi jelas dan memiliki dasar hukum pasti tanpa harus menginduk pada UU Koperasi yang secara substansi belum mengakomodir prinsip syari’ah dalam operasionalnya.

\section{Nilai Dasar Pembentukan UU BMT dalam Bingkai Ius Constituendum}

Dalam rangka upaya pembentukan suatu aturan hukum termasuk mengenai wacana pembentukan aturan hukum bagi koperasi syari'ah yaitu BMT, maka penulis akan menyajikan gambaran konseptual dalam kajian teori hukum . Upaya 
pembentukan hukum dalam ilmu hukum disebut dengan ius constituendum, singkatnya bahwa ius constituendum adalah hukum yang dicitacitakan atau hukum yang akan berlaku dimasa mendatang.

Konsep dan kajian teori hukum yang penulis tawarkan adalah mengenai 3 nilai dasar yang harus diperhatikan dalam rangka pembentukan aturan hukum Bagi BMT sebagai Koperasi Syari'ah. ke3 dasar tersebut adalah filosofis, sosiologis dan yuridis. Oleh Gustav Radbruck 3 dasar tersebut nantinya akan melahirkan 3 nilai yaitu Keadilan, kemanfaatan dan kepastian. ${ }^{31}$

Sejalan dengan pendapat yang dikemukakan Gustav Radbruck, Prof. Dr. Jimly Asshiddiqie hanya menambahkan satu dasar pembentukan suatu aturan hukum yaitu dasar politis. ${ }^{32}$

Dasar Filosofis / Filosofiche Geltung merupakan suatu landasan ideal yang mengandung cita-cita kolektif masyarakat tentang nilai luhur, dimana cita-cita luhur ini terkandung dalam Pancasila dan UUD 1945. Olehkarenanya suatu peraturan dibentuk berdasarkan cita-cita dasar tersebut karna secara filosofis jika isi yang terkandung didalamnya sesuai dengan cita hukum bangsa (rechtsidee) sebagai nilai positif tertinggi.

Perubahan yang terjadi didalam Undang-Undang Koperasi No.17 Tahun 2012 dianggap telah mereduksi semangat demokrasi ekonomi, kekeluargaan dan gotong royong yang di amanahkan oleh Undang-Undang Dasar 1945, dimana dalam kebijakan barunya, tersirat bahwa keberadaan suatu koperasi sangat dipengaruhi oleh keberadaan modal bukan lagi karena anggota dan oleh anggota serta untuk kesejahteraan para anggotanya.

Sebagai dasar filosofis dalam pembentukan UU Koperasi syari'ah bagi BMT selain pancasila dan UUD 1945 sebagai recht idea tertinggi, semangat syari'ah yang terdapat dalam Al-qur'an dan Hadist harus pula diakomodir dalam pembentukan UU Koperasi syari'ah. Hal inipun sebagai konsekuensi dari Teori Receptie In Complexiu/ penerimaan Hukum Islam sepenuhnya .

${ }^{31}$ Soerjono Soekanto, Beberapa Permasalahan Hukum dalam Kerangka Pembangunan di Indonesia, (Jakarta: Yayasan Penerbit UI, 1975), hlm. 5-6.

32 Jimly A, Peribal Undang-Undang, (Jakarta: Rajawali Pers, 2011), hlm.117 
Teori ini dikemukakan oleh Prof. Mr.Loedewijk Willm Cristian Van Den Berg (1845-1927), yang menyatakan bahwa bagi orang islam sepenuhnya berllaku penuh Hukum Islam karena ia telah memeluk agama Islam walaupun dalam pelaksanaannya terdapat penyimpangan-penyimpangan. ${ }^{33}$

Sebagai bentuk dari diberlakukannya hukum Islam bagi umat Islam maka dalam kaitannya dengan pembentukan aturan hukum yang terkait dengan aktivitas umat Islam, maka harus pula mengakomodir nili-nilai dalam hukum Islam seperti halnya mengenai aturan hukum bagi BMT yang merupakan Koperasi Syari'ah.

Landasan sosiologis / soziologische geltung bahwa suatu peraturan hukum memiliki kekuatan berlaku secara sosiologis apabila kekuatan berlakunya suatu peraturan hukum merupakan kenyataan dalam masyarkat artinya bahwa peraturan tersebut efektif dan diterima oleh masyarakat terlepas dari apakah peraturan tersebut memenuhi persyaratan formil atau tidak. Artinya bahwa setiap hukum harus memuat tuntutan kebutuhan masyarakat karena dengan landasar sosiologis ini nantinya akan melahirkan nilai kemanfaatan. Pada kenyataannya secara sosiologis UU Koperasi Tahun 2012 dianggap tidak sesuai dengan kebutuhan seluruh masyarakat terlebih terhadap keberadaan BMT. Oleh karenanya menjadi suatu keharusan bagi BMT untuk memiliki aturan hukum tersendiri sebagaimana UU Perbankkan syari'ah .

Terkait dengan pembentukan UU Koperasi baru, secara substansi akan penulis akan sajikan berdasarkan 3 hal utama yang menjadi fokus utama gagasan materi UU Koperasi Syari'ah adalah mengenai:

a. Kelembagaan yaitu dalam kaitannya tentang BMT sebagai suatu lembaga keuangan yang dalam aktifitasnya berdampak pada responsibility (pertanggungjawaban) secara hukum.

b. Keorganisasian adalah mengenai organ suatu lembaga yang tersusun secara sistematis sehingga tanggung jawab

${ }^{33}$ Sayuti Thalib, Receptie a Contrario (Hubungan Antara Hukum Adat dan Hukum Islam), (Jakarta: Academika, 1980), hlm. 7. 
masing-masing dapat terorganisir dengan rapi.

c. Permodalan terkait dengan sistem permodalan dan bentuk modal yang ada di koperasi

Pada aspek kelembagaan yang paling disoroti oleh BMT adalah mengenai pemilihan badan hukum koperasi yang berdasarkan informasi dari sekretaris Puskopsyah Kota Metro bahwa pemilihan badan hukum koperasi sudah merupakan pilihan badan usaha berbadan hukum yang pas untuk BMT. ${ }^{34}$ tanggapan serupa juga terlontar dari fuad Ashari selaku skertaris BMT arsyada , bapak Husni selaku menejer BMT Fadjar Metro dalam rapat pembentukan asosiasi BMT di Puskopsyah. Hanya saja dalam pelaksanaannya harus berlandaskan pada prinsip-prinsip syari'ah. Menurut Fuad Asari karena inilah yang membedakan BMT dengan koperasi konvensional.

BMT sebagai Koperasi syari'ah harus diusung dengan semangat demokrasi dan syari'ah. Semangat demokrasi sebagai pengejawantahan semangat demokrasi di negara Indonesia dan semangat syariah sebagai ciri khas islami yang menjunjung tinggi prinsip-prinsip syariah seperti keadilan, ketauhidan, keseimbangan dalam setiap aktivitas yang dilakukan.

Sebagai konsekuensi badan hukum koperasi maka BMT sebagai Badan Hukum harus memiliki organ yang jelas sebagaimana yang tersirat dalam teori Organ sebagai syarat suatu badan usaha dikatakan sebagai badan hukum yaitu harus memiliki organ yang jelas yang mampu menggambarkan fungsifungsi pada masing-masing organ sehingga BMT dapat difiksikan sebagai manusia yang konsekuensinya memiliki hak dan kewajiban hukum.

Otto Von Gierke mengatakan mengenai teori organ bahwa badan usaha sebagai badan hukum sama halnya seperti manusia sebagai suatu realitas sesungguhnya dalam pergaulan hukum, artinya bahwa teori ini menunjukkan bahwa badan usaha sebagai badan hukum itu ada dan konsekuensinya bahwa badan hukum memiliki kehendak dan kemauan sendiri melalui alat perlengkapan

${ }^{34}$ Hasil wawancara dengan Kukuh selaku Sekertaris Puskopsyah Metro Pada 28 September 2014. 
badan hukum tersebut. ${ }^{35}$

Teori organ diatas diperkuat lagi oleh teori kenyataan yuridis EM, Meijers yang menegaskan bahwa sebagai badan hukum diartikan bahwa badan usaha sebagai badan hukum merupakan realitas , konkret dan riil sama halnya seperti manusia. ${ }^{36}$

Landasan Yuridis atau Juridische Geltung artinya bahwa suatu peraturan hukum akan berlaku secara yuridis jika persyaratan formal pembentukan suatu peraturan telah terpenuhi. Landasan yuridis ini didasari oleh suatu pemikiran bahwa hukum merupakan kesatuan sitem norma.

Landasan politis artinya bahwa keberadaan suatu aturan hukum merupakan suatu upaya menuangkan cita-cita kolektif masyarakat Indonesia dalam suatu aturan hukum melalui kekuatan politis yang ada dengan kata lain dasar ini memiliki keterkaitannya dengan kekuasaan yang berperan sebagai legitimasi suatu aturan hukum.

\section{Simpulan}

Keadilan merupakan cita hukum tertinggi, Dalam rangka mencipatakan keadilan bagi aktivitas BMT keberadaan hukum sebagai dasar lagalisasi aktivitas yang dilakukan adalah suatu keharusan. Hal inipun sebagai konsekuensi dari prinsip rechtstaat yang dijalankan di Indonesia.

Dengan dibatalkannya UU Koperasi No.17 Tahun 2012 maka perlu bagi BMT memiliki aturan hukum tersendiri sebagai payung hukum bagi aktivitas BMT sebab Koperasi dan BMT (yang disejajarkan dengan Koperasi Syari'ah) berbeda secara operasional dan prinsip. Olehkarenanya pembentukan UndangUndang Koperasi Syari'ah sebagai dasar Hukum BMT harus segera dilaksanakan. Dalam rangka pembentukan UU Koperasi Syari'ah maka hendaknya perlu diperhatikan 3 nilai dasar, nilai dasar tersebut adalah: hlm. 193.

${ }^{35}$ Pipin Syarifin, Pengantar Ilmu Hukum, (Bandung: Pustaka Setia, 1999), ${ }^{36}$ Ibid., hlm. 7. 
1. Landasan sosiologis / Soziologische Geltung bahwa suatu peraturan hukum memiliki kekuatan berlaku secara sosiologis bila memuat tuntutan kebutuhan masyarakat karena dengan landasar sosiologis ini nantinya akan melahirkan nilai kemanfaatan.

2. Landasan Yuridis atau Juridische Geltung artinya bahwa suatu peraturan hukum akan berlaku secara yuridis jika persyaratan formal pembentukan suatu peraturan telah terpenuhi. Landasan yuridis ini didasari oleh suatu pemikiran bahwa hukum merupakan kesatuan sitem norma.

3. Landasan politis artinya bahwa keberadaan suatu aturan hukum merupakan suatu upaya menuangkan cita-cita kolektif masyarakat Indonesia dalam suatu aturan hukum melalui kekuatan politis yang ada dengan kata lain dasar ini memiliki keterkaitannya dengan kekuasaan yang berperan sebagai legitimasi suatu aturan hukum. 


\section{DAFTAR PUSTAKA}

Amalia, Euis, Keadilan Distributif Dalam Ekonomi Islam, Jakarta: PT Rajagrafindo Persada, 2009.

Amirudin dan Zainal Asikin, Pengantar Metode Penelitian Hukum, Jakarta: Rajawali Pers, 2003.

Ashshofa, Burhan, Metode Penelitian Hukum, Jakarta: Rineka Cipta, 2002.

Asshidieqi, Jimly, Peribal Undang - Undang, Jakarta: Rajawali Pers, 2011.

Bruggink, J.J.H., Refleksi tentang Hukum. Alih Bahasa: Arief Sidharta. Bandung: Citra Aditya Bakti, 2000.

Bukhori, Nur S, Koperasi Syariah Teori dan Praktik, Tanggerang Selatan: Pustaka Aufa Media, 2012,

Hamdan, M., Politik bukum Pidana, Jakarta: P'T. Raja grafindo Persada, 1997.

Hartono, Sunaryati, Politik Hukum Menuju Sistem Hukum Nasional, Bandung: Alumni, 1991.

L Tanya, Bernard, Dkk, Teori Hukum Strategi tertib Manusia Lintas Ruang dan Generasi Yogyakarta: Genta Publishing, 2010.

Muhammad, Abdul Kadir, Hukum dan Penelitian Hukum, Jakarta: PT. Citra Aditya Bhakti, 2004.

Sudikno, Mengenal Hukum, Yogyakarta: Liberty, 1999.

Sunggono, Bambang, Metode Penelitian Hukum, Jakarta : Raja Grafindo Persada, 2002.

Thalib, Sayuti, Receptie a Contrario (Hubungan antara Hukum Adat dan Hukum Islam), Jakarta: Academika, 1980.

Wahyono, Padmo, Indonesia Negara Berdasatkan atas hukum, Cet. IV, Jakarta: Ghalia Indonesia, 1996. 